\title{
Are butyrophenones effective for the treatment of primary headache in the emergency department?
}

\author{
Lim Beng Leong, MBBS, MRCS $(A \& E)^{*}$; Anne-Maree Kelly, MD, FACEM ${ }^{\dagger}$
}

\section{ABSTRACT}

Objectives: Butyrophenones have been reported to provide effective migraine relief in the emergency department (ED). We conducted a systematic review of the evidence for their use in the ED.

Data source: We searched the Cochrane, Medline, Embase, and CINAHL databases.

Study selection: Included studies were randomized trials of a parenteral butyrophenone (droperidol, haloperidol) versus placebo or a comparator in migraine or benign headache with results available in English. Study quality was determined using the Jadad score. Six articles were included.

Data extraction: Primary outcomes were subjective or objective headache relief ( $>50 \%$ improvement in visual analogue scale scores). Secondary outcomes included side effects. We reported pooled odds ratios (ORs) with their $95 \%$ confidence intervals (Cls) for subjective or objective headache relief for butyrophenones versus placebo or comparator agents.

Data synthesis: Three studies reported subjective headache relief with a butyrophenone versus placebo or meperidine in migraine. Two studies reported objective headache relief with droperidol versus prochlorperazine, whereas one study compared droperidol versus olanzapine in benign headache. The pooled OR for subjective headache relief was $8.08(95 \% \mathrm{Cl} 1.54-42.30)$ for a butyrophenone versus placebo, whereas it was 1.50 (95\% Cl 0.33-6.77) for droperidol versus meperidine in migraine. The pooled OR for objective headache relief was $2.96(95 \% \mathrm{Cl}$ 1.36-6.43) for droperidol versus prochlorperazine in benign headache. Rates of side effects were 10 to $45 \%$; akathesia and sedation were the most common.

Conclusions: Butyrophenones are effective for the relief of migraine or benign headache. However, adverse effects make it difficult to recommend butyrophenones above agents with similar effectiveness and fewer problems.

\section{RÉSUMÉ}

Objectif : Il a été signalé que les butyrophénones soulageaient les migraines dans les services d'urgence. Nous avons procédé à une analyse systématique sur leur utilisation à l'urgence.

Source des données: Nous avons interrogé les bases de données Cochrane, Medline, Embase et CINAHL.

Sélection des études : Nous avons retenu les essais randomisés d'un butyrophénone parentéral (dropéridol, halopéridol) contre un placebo ou un comparateur en cas de migraine ou de céphalée bénigne. Les résultats devaient être disponibles en anglais. Nous avons évalué la qualité des essais selon le score de Jadad. Six articles ont été retenus.

Extraction des données : Les principaux critères d'évaluation étaient le soulagement subjectif ou objectif de maux de tête (>50\% d'amélioration selon l'échelle visuelle analogique). Les critères secondaires d'évaluation étaient entre autres les effets secondaires. Nous avons inclus les rapports de cotes combinés $(\mathrm{RC})$ avec intervalle de confiance à $95 \%$ (IC) pour le soulagement subjectif ou objectif de maux de tête pour le groupe butyrophénones par rapport au groupe placebo ou autres comparateurs.

Synthèse des données : Trois études ont signalé un soulagement subjectif de maux de tête avec un butyrophénone par rapport au groupe placebo ou à la mépéridine pour les cas de migraine. Deux études ont fait état d'une amélioration objective de céphalées avec le dropéridol par rapport au prochlorpérazine tandis qu'une autre étude comparait le dropéridol à l'olanzapine pour les céphalées bénignes. Le RC combiné pour le soulagement subjectif de maux de tête était de 8,08 (IC à $95 \%$, de 1,54 à 42,30) pour un butyrophénone contre un placebo alors qu'il était de 1,50 (IC à $95 \%$, de 0,33 à 6,77) pour le dropéridol par rapport à la mépéridine pour les cas de migraine. Le RC combiné pour le soulagement objectif de maux de tête était de 2,96 (IC à $95 \%$, de 1,36 à 6,43 ) pour le dropéridol par rapport à la prochlorpérazine pour les cas de céphalées bénignes. Les taux d'effets secondaires étaient de 10 à $45 \%$, l'akathésie et la sédation étant les réactions les plus courantes.

From the *Emergency Department, Tan Tock Seng Hospital, Singapore; and †Joseph Epstein Centre for Emergency Medicine Research at Western Health and The University of Melbourne, Melbourne, Australia.

Correspondence to: Dr. Lim Beng Leong, Tan Tock Seng Emergency Department, 11, Jalan Tan Tock Seng, Singapore 308433; Beng_Leong_ Lim@ttsh.com.sg.

This article has been peer reviewed. 
Conclusion : Les butyrophénones sont efficaces pour le soulagement de migraines ou de céphalées bénignes. Toutefois, vu les effets indésirables, il est difficile de privilégier l'utilisation des butyrophénones plutôt que celle d'agents offrant une efficacité similaire et ayant moins d'effets néfastes.

Keywords: butyrophenones, emergency, migraine
Migraine is a common complaint in the emergency department (ED) and accounts for up to $5 \%$ of visits. ${ }^{1}$ The goals of treatment include pain relief, rehydration, and alleviation of associated symptoms such as nausea and vomiting. ${ }^{2}$ Wide variation in the agents used in the ED to treat acute migraine has been reported. ${ }^{1,3}$ In addition, some of the known therapies for treatment of acute migraine headache have been reported to have significant adverse effects. Opioids have been reported to produce rebound headache following their use in acute migraine ${ }^{3,4}$ and progression to chronic migraine with repeated use. ${ }^{5}$ Triptans, although widely used in acute migraine, have a very small risk of adverse cardiovascular effects. ${ }^{6}$

It has been suggested that the butyrophenone class of drugs (droperidol and haloperidol) might be effective in acute migraine. ${ }^{7,8}$ Butyrophenones are thought to act by effecting the dopamine $2\left(\mathrm{D}_{2}\right)$ receptor in the brain. ${ }^{9}$ The $\mathrm{D}_{2}$ receptors are relatively abundant in the brainstem nuclei and sympathetic ganglia and nerves, through which they may regulate autonomic visceral, gastrointestinal, and hemodynamic responses frequently associated with migraine. ${ }^{9}$

The aim of this evidence-based report is to identify and summarize the relevant evidence for the effectiveness of butyrophenones in the treatment of acute migraine headache in the ED.

\section{QUESTION}

In adult patients with moderate to severe migraine headache, are butyrophenones effective for headache relief?

\section{METHODS}

We identified relevant studies by searching the Cocbrane Library, Medline, Embase, and CINAHL databases using the search expression [Exp butyrophenones OR haloperidol OR droperidol] AND [migraine OR migraine disorders OR migraine AND disorders] OR [benign headache]. We included studies involving benign headache as they likely included migraine headache as well in their samples, and it can be challenging for emergency physicians to differentiate migraine from other benign headache, such as tension headache, in the ED setting. In addition, the differentiation between the types of benign headaches in the ED setting does not appear to be important in their subsequent treatment, as reported by Trainor and Miner. ${ }^{10}$ They reported in their prospective observational study in the ED setting that there was no difference in the treatment used and rates of pain relief across agents, including sumatriptan, droperidol, narcotics, and nonsteroidal antiinflammatory drugs (NSAIDs) in migraine and migrainous and tension-type headaches.

Titles and abstracts were reviewed to identify papers potentially addressing the research question. The full texts of these were obtained and reviewed. A hand search of the reference lists of published papers was also conducted.

Studies were selected for inclusion if they were randomized and blinded trials of a parenterally administered butyrophenone (droperidol, haloperidol) versus placebo or a parenterally administered comparator for the treatment of acute migraine or benign headache in adults with results available in English. Study quality was measured by calculation of the Jadad score. ${ }^{11}$ Two independent reviewers independently screened suitable articles using our inclusion criteria. They discussed and decided on the articles finally included in the study. The Jadad score for each of these was assigned after discussion between the reviewers.

The primary outcome of interest was relief of headache within 2 hours of treatment for a single bolus or up to 3 hours for an infusion of the studied medication. We selected the 2-hour duration for pain relief for a bolus dose as it was clinically relevant and practical in the ED and recommended by the International Headache Society (IHS) committee on clinical trials on migraine. ${ }^{12}$ We decided on the 3 -hour limit for pain relief for an infusion as we felt that it would likely have a slower onset of action and response time. Secondary outcomes included relief of associated symptoms, mean change in visual analogue scale (VAS) scores, use of rescue medications within 24 hours, and side effects. 
Table 1. Papers investigating a butyrophenone versus placebo in migraine

\begin{tabular}{|c|c|c|c|c|c|c|}
\hline $\begin{array}{l}\text { Author, date, and } \\
\text { country }\end{array}$ & Patient group & $\begin{array}{l}\text { Study type (level of } \\
\text { evidence) }\end{array}$ & Outcomes & Key results & Study weaknesses & $\begin{array}{l}\text { Jadad } \\
\text { score }\end{array}$ \\
\hline \multirow[t]{3}{*}{$\begin{array}{l}\text { Honkaniemi J et al, } \\
\text { 2006, Finland }{ }^{13}\end{array}$} & \multirow[t]{3}{*}{$\begin{array}{l}40 \text { adult } \\
\text { patients with } \\
\text { migraine } \\
\text { using IHS } \\
\text { definitions }\end{array}$} & \multirow[t]{3}{*}{$\begin{array}{l}\text { PRCT (double blind) } \\
\text { comparing IV } \\
\text { infusion of } 5 \mathrm{mg} \\
\text { haloperidol in } \\
500 \mathrm{~mL} \text { normal } \\
\text { saline over } 30 \\
\text { min vs placebo }\end{array}$} & $\begin{array}{l}\text { Total or almost total } \\
\text { pain relief leading } \\
\text { to discharge } \\
1-3 \mathrm{hr} \text { post- } \\
\text { treatment }\end{array}$ & $\begin{array}{l}\text { More patients with total or } \\
\text { almost total pain relief in } \\
\text { haloperidol group (16/20 } \\
\text { vs } 3 / 20 ; p<.0001) ; \\
\text { clinical success rate } 80 \% \text {; } \\
\text { ARR } 65 \% \text {; NNT } 1.5(95 \% \\
\text { Cl } 1.1-2.4)\end{array}$ & \multirow[t]{3}{*}{$\begin{array}{l}\text { Small sample size and } \\
\text { did not look at other } \\
\text { important side } \\
\text { effects of } \\
\text { haloperidol, such as } \\
\text { prolonged QTc }\end{array}$} & \multirow[t]{3}{*}{$4 / 5$} \\
\hline & & & $\begin{array}{l}\text { Improvement in } \\
\text { VAS values } \\
1-3 \text { hr post- } \\
\text { treatment }\end{array}$ & $\begin{array}{l}\text { Lower mean VAS post- } \\
\text { haloperidol vs placebo } \\
\text { ( } 2.3 \text { vs } 6.2 ; p<.0001)\end{array}$ & & \\
\hline & & & Side effects & $\begin{array}{l}\text { More patients in haloperidol } \\
\text { group developed side } \\
\text { effects ( } 9 / 20 \text { for motor } \\
\text { agitation or sedation vs } \\
1 / 20 \text { for visual disturbance } \\
\text { in placebo group) }\end{array}$ & & \\
\hline \multirow[t]{7}{*}{$\begin{array}{l}\text { Silberstein SD et } \\
\text { al, 2003, United } \\
\text { States }^{14}\end{array}$} & \multirow[t]{7}{*}{$\begin{array}{l}305 \text { adult } \\
\text { patients with } \\
\text { moderate to } \\
\text { severe } \\
\text { migraine } \\
\text { using IHS } \\
\text { definitions }\end{array}$} & \multirow[t]{7}{*}{$\begin{array}{l}\text { PRCT } \\
\text { (multicentred, } \\
\text { double blind) } \\
\text { comparing } \\
\text { various doses of } \\
\text { IM droperidol } \\
(0.1,2.75,5.5, \\
8.25 \mathrm{mg}) \text { with } \\
\text { placebo }\end{array}$} & $\begin{array}{c}\text { Headache relief } 2 \mathrm{hr} \\
\text { post-treatment }\end{array}$ & $\begin{array}{l}\text { More patients had headache } \\
\text { relief at } 2 \text { hr with } \\
\text { potentially therapeutic } \\
\text { doses of droperidol (2.75- } \\
8.75 \mathrm{mg} \text { ) than placebo: } \\
153 / 181 \text { vs } 35 / 61 \text {; } \\
p<.002) \text {; clinical success } \\
\text { rate } 84.5 \% \text {; ARR } 27.1 \% \text {; } \\
\text { NNT } 3.7 \text { (95\% Cl } 2.5-7.3 \text { ) }\end{array}$ & \multirow[t]{7}{*}{$\begin{array}{l}\text { No mention regarding } \\
\text { the relative } \\
\text { contribution to the } \\
\text { sample size by each } \\
\text { centre, ie, whether } \\
\text { there is } \\
\text { overrepresentation } \\
\text { by one centre }\end{array}$} & $4 / 5$ \\
\hline & & & $\begin{array}{l}\text { Use of rescue } \\
\text { medications } \\
\text { within } 24 \text { hr post- } \\
\text { treatment }\end{array}$ & $\begin{array}{l}\text { Less patients required } \\
\text { rescue medications at } \\
24 \mathrm{hr} \text { compared to } \\
\text { placebo group (38/181 vs } \\
27 / 61 ; p<.05 \text { ) }\end{array}$ & & \\
\hline & & & \multirow[t]{2}{*}{$\begin{array}{l}\text { Relief of associated } \\
\text { symptoms } \\
\text { (nausea, } \\
\text { vomiting, } \\
\text { photophobia, } \\
\text { phonophobia) } \\
\text { post-treatment }\end{array}$} & $\begin{array}{l}\text { Droperidol } 2.75 \mathrm{mg} \text { reduced } \\
\text { nausea for } 4 \mathrm{hr} \text {, } \\
\text { photophobia and } \\
\text { phonophobia for } 12 \mathrm{hr} \\
\text { compared to placebo } \\
\text { ( } p \text { value }<.05 \text { ) }\end{array}$ & & \\
\hline & & & & $\begin{array}{l}\text { Droperidol } 8.25 \mathrm{mg} \text { reduced } \\
\text { all associated symptoms } \\
\text { for } 48 \mathrm{hr} \text { compared to } \\
\text { placebo ( } p \text { value }<.05 \text { ) }\end{array}$ & & \\
\hline & & & \multirow[t]{3}{*}{ Side effects } & $\begin{array}{l}\text { 92/305 patients had adverse } \\
\text { effects; most commonly } \\
\text { anxiety, akathesia, or } \\
\text { somnolence }\end{array}$ & & \\
\hline & & & & $\begin{array}{l}\text { No prolonged QTc or } \\
\text { hypotension noted }\end{array}$ & & \\
\hline & & & & $\begin{array}{l}\text { Side effects did not show } \\
\text { linear dose dependence }\end{array}$ & & \\
\hline
\end{tabular}

For the analysis, we calculated the weighted rate of headache relief, absolute risk reduction (ARR), number needed to treat (NNT), odds ratio (OR), and 95\% confidence interval (CIs) for headache relief by each butyrophenone versus placebo or comparator in each study. We weighted each study according to the number of subjects enrolled. We chose to take the more conservative approach of pooling studies with a 
Table 2. Papers of droperidol versus comparator in migraine or benign headache

Author, date, and country

Richman

PB et al,

2002,

United

States $^{15}$
Study type (level of Patient group

29 adult patients with migraine using IHS definitions
PRCT (double blind) Prop comparing IM $2.5 \mathrm{mg}$ droperidol vs IM $1.5 \mathrm{mg} / \mathrm{kg}$ meperidine

Outcomes

Key results

\section{each arm who felt}

well and were

discharged 30 min post-treatment
Miner JR et 168 adult al, 2001, United

States $^{16}$ patients with benign headache as judged by their EP
Weaver CS 95 adult et al, 2004, United States $^{17}$ patients with benign headache as judged by their EP
PRCT, single blind; comparing parenteral droperidol (IM $5 \mathrm{mg}$ or IV 2.5 $\mathrm{mg}$ ) vs prochlorperazine (10 mg IM or IV)

Mean change in VAS 30 min posttreatment

Side effects at $30 \mathrm{~min}$ post-treatment

Proportion of patients in each arm who reported $>50 \%$ change in VAS at 60 min posttreatment

Mean change in VAS 60 min posttreatment

Proportion of patients requiring rescue medications at $60 \mathrm{~min}$ post-treatment

Proportion of patients with side effects at 60 min posttreatment

PRCT, double blind at 2 centres; comparing IV 2.5 mg droperidol vs IV 10 mg prochlorperazine

Proportion of patients in each arm who reported $>50 \%$ change in VAS at 30 min posttreatment

Mean percentage decrease in VAS in each arm at 30 min post-treatment

Proportion of patients in each arm requiring rescue medications at 30 min posttreatment

Proportion of patients with side effects at 60 min posttreatment
Troperido arm vs $8 / 14$ ol arm vs 8/14 in meperidine am; $p=.61$ ); clinical success $67 \%$; ARR 9.6\%; NNT 11 (95\% Cl: not reported as the two treatments not significantly different)

No significant difference (47 vs $37 \mathrm{~mm} ; p=.33$ )

$1 / 15$ vs $2 / 14$ had sedation in droperidol vs meperidine arms; 2/15 in droperidol arm had akathesia

Significant difference (74/82 in droperidol arm vs 59/86 in prochlorperazine arm: $p=.017) ;$ ARR $21.6 \%$; NNT 5 (95\% Cl 3.0-10.1)

Significant difference $(81.4 \%$ in droperidol arm vs $66.9 \%$ in prochlorperazine arm; $p=.001)$

No significant difference (13/82 in droperidol arm vs 18/86 in prochlorperazine arm; $p=.12$ )

No significant difference (13/82 in droperidol arm vs 8/86 in prochlorperazine arm; $p=.19$ )

Akathesia was the most common reported side effect

Significant difference $(40 / 48$ in droperidol arm vs 34/47 in prochlorperazine arm; $p<.01)$; ARR 11.0\%; NNT 10 (95\% Cl -18 to 4$)$

No significant difference $(79.1 \%$ in droperidol arm vs $72.1 \%$ in prochlorperazine arm; $p=.23)$

No significant difference $6 / 48$ in droperidol arm vs 6/47 in prochlorperazine arm; $p=1.0$ )

No significant difference in akathesia (5/48 in droperidol arm vs 9/47 in

prochlorperazine arm; $p=.25$ )

No other side effects reported in each arm
Study weaknesses

Small sample size,

$3 / 5$ no follow-up of patients post discharge and did not look at other important side effects of droperidol such as prolonged QTc and hypotension

Convenient sample groups; investigators not blinded to the drug used and IV or IM formulations not randomized within the 2 arms; larger dose of IM $5 \mathrm{mg}$ droperidol used in the study instead of IM $2.5 \mathrm{mg}$

Convenient sample group, the relative contribution at each centre not reported, premature termination of study before calculated sample size of 460 patients was reached owing to shortages of IV prochlorperazine and the FDA "black box" warning of torsades de pointes with droperidol 


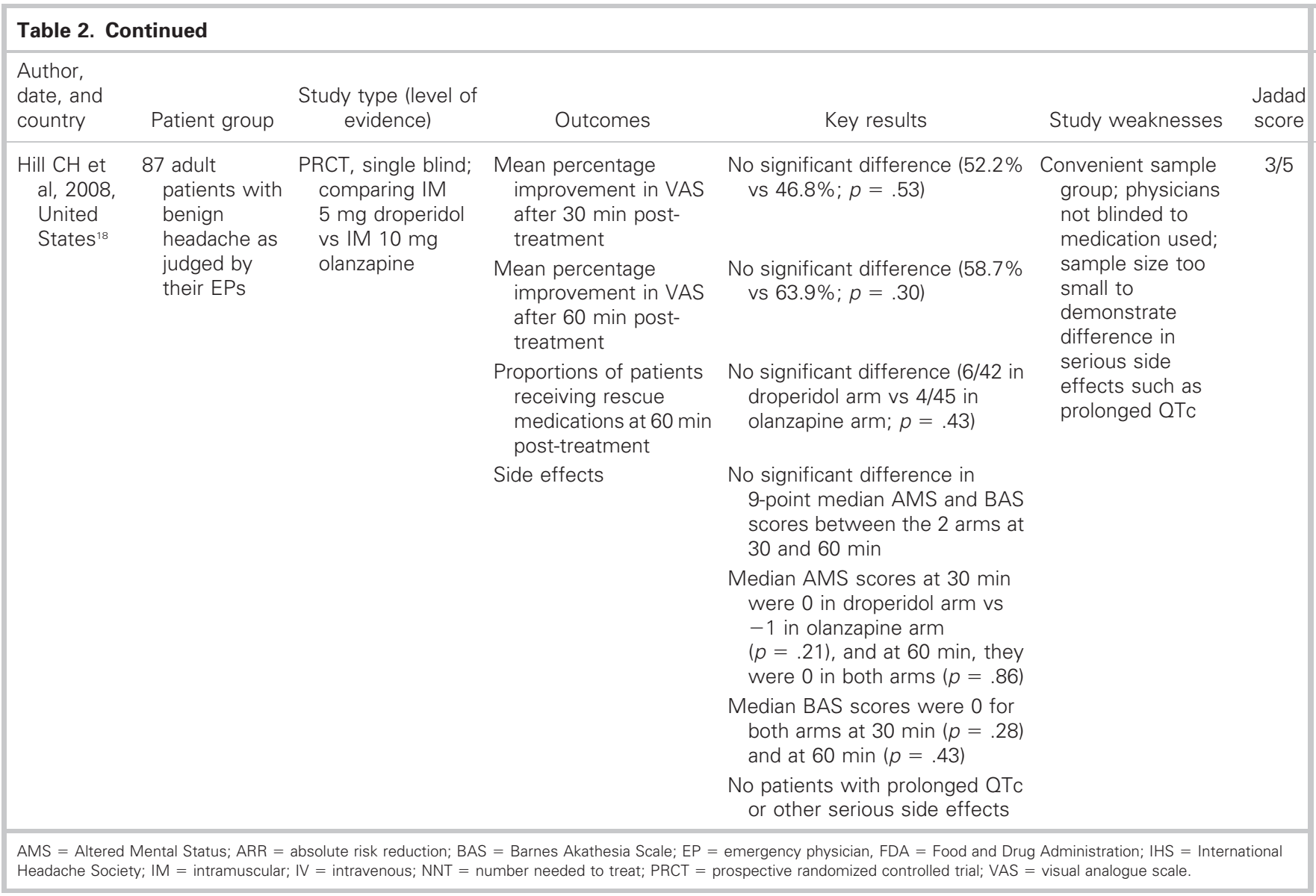

random-effects analysis. We performed all analyses using RevMan version 5 (Cochrane Collaboration, Copenhagen, Denmark).

\section{RESULTS}

We identified 36 papers, of which 6 met the inclusion criteria. Two of these studies compared a butyrophenone to placebo in the treatment of migraine. ${ }^{13,14}$ One compared intravenous (IV) haloperidol to placebo, ${ }^{13}$ whereas the other compared intramuscular (IM) droperidol to placebo using four different dosage regimens. ${ }^{14}$ The remaining four studies compared parenteral droperidol to a comparator drug in the treatment of migraine or benign headache. ${ }^{15-18}$ The comparator drugs were meperidine, prochlorperazine, or olanzapine. The details of these papers are shown in Table 1 and Table 2.

The most common primary outcome studied in these trials was subjective or objective relief of headache at intervals from 30 minutes to 2 hours after treatment following a bolus dose or from 1 to 3 hours following an infusion of a butyrophenone. Objective headache relief was defined as $>50 \%$ improvement in VAS scores. Three studies reported proportions of patients with subjective headache relief 1 to 3 hours post administration of a butyrophenone compared to placebo or meperidine in the treatment of migraine. ${ }^{13-15}$ The weighted average rate of subjective headache relief 1 to 3 hours after treatment by a butyrophenone in these three trials was $82.8 \%(n=216)$.

Two studies reported proportions of patients with objective headache relief within 30 to 60 minutes after administration of droperidol compared to prochlorperazine in the treatment of benign headache. ${ }^{16,17}$ The weighted average proportion of patients with objective headache relief at this interval was $87.7 \%(n=130)$ in the two trials. The remaining study reported mean percentage improvement in VAS scores of $52.2 \%$ and $58.7 \% 30$ and 60 minutes post-treatment with IM droperidol, respectively, when compared to IM olanzapine in the treatment of benign headache. ${ }^{18}$ 


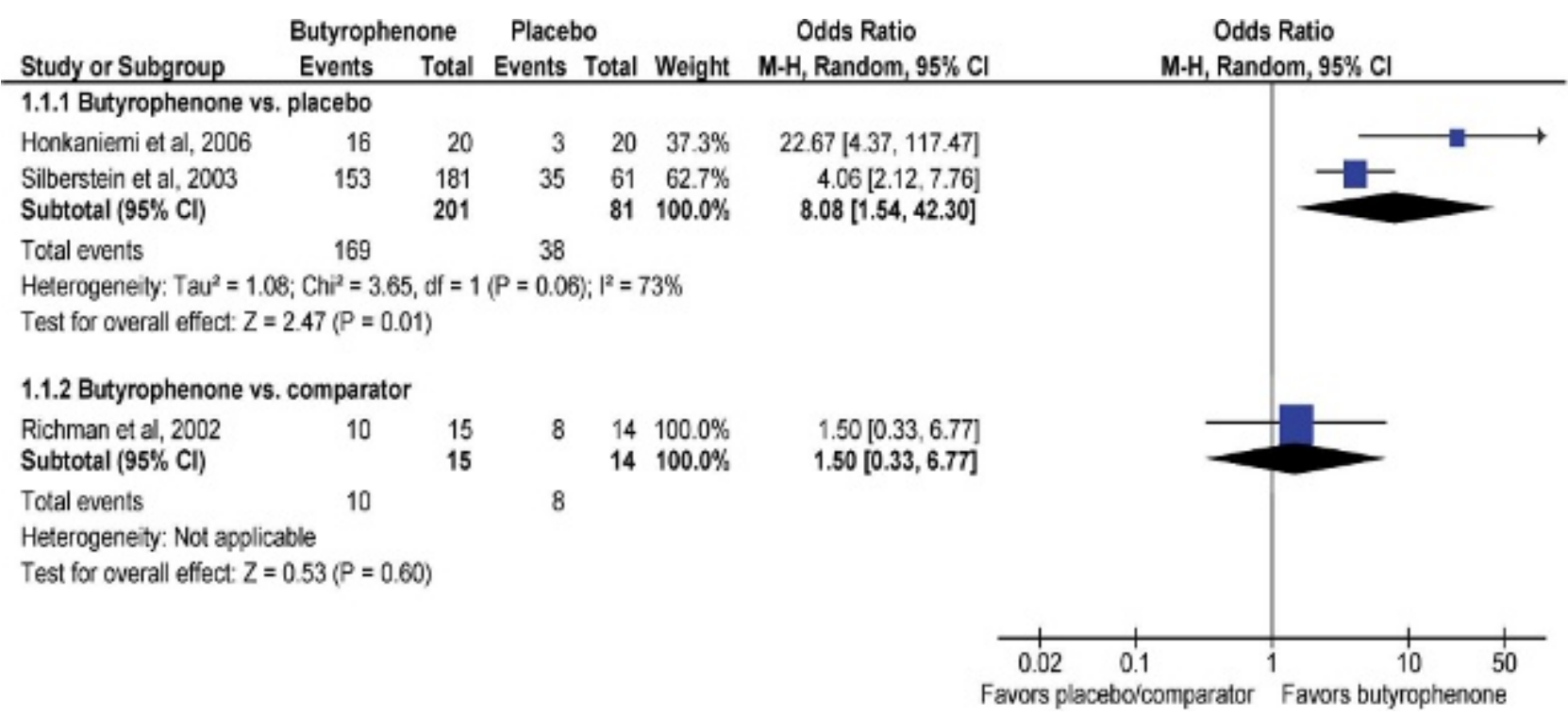

Figure 1. Forest plot for subjective headache relief for each butyrophenone versus placebo or comparator. Event $=$ subjective headache relief within 3 hours post-treatment.

There were statistically significant differences for subjective or objective headache relief for haloperidol and droperidol versus placebo and droperidol versus prochlorperazine in the treatment of migraine or benign headache. There were no statistically significant differences for subjective headache relief for droperidol versus meperidine in migraine treatment and for mean percentage improvement in VAS scores for droperidol versus olanzapine in the treatment of benign headache.

The pooled OR for subjective headache relief within 3 hours of treatment was 8.08 (95\% CI 1.54-42.30) for a butyrophenone versus placebo in migraine treatment. The OR for subjective headache relief within 30 minutes of treatment was 1.50 (95\% CI 0.33-6.77) for droperidol versus meperidine in migraine treatment. These are demonstrated in the forest plot in Figure 1. The ARR for subjective headache relief was
$65 \%$ and $27.1 \%$ for haloperidol and droperidol, respectively, compared to placebo. The ARR for droperidol compared to meperidine was $9.6 \%$. When compared to placebo, the NNT for subjective headache relief was 1.5 (95\% CI 1.1-2.4) and 3.7 (95\% CI 2.5-7.3) for haloperidol and droperidol, respectively. When compared to meperidine, the NNT for subjective headache relief was 10.4 (95\% CIs were not reported as the two treatments were not significantly different).

The pooled OR for objective headache relief within 1 hour of treatment was 2.96 (95\% CI 1.36-6.43) for droperidol versus prochlorperazine in the treatment of benign headache. These are demonstrated in the forest plot in Figure 2. The pooled ARR and NNT for objective headache relief for droperidol versus prochlorperazine was $17.8 \%$ and 5.6 (95\% CI $3.7-12.3)$, respectively.

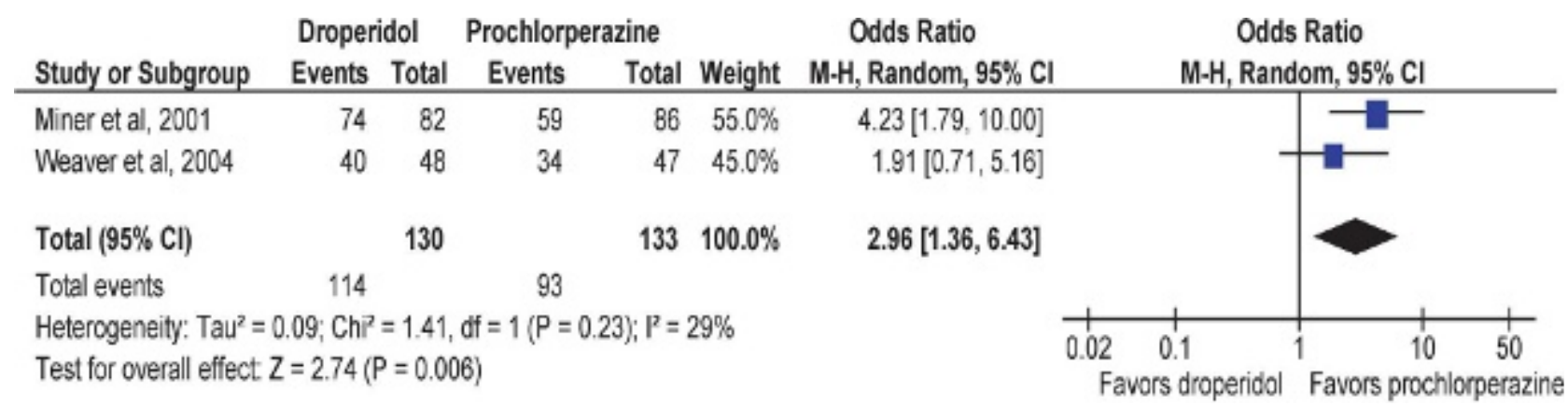

Figure 2. Forest plot for objective headache relief for droperidol versus prochlorperazine. Event $=$ objective headache relief within 1 hour post-treatment. 
Rates of side effects to butyrophenone were reported to be 10 to $45 \%$. Akathesia and sedation were the most commonly reported side effects. In only one article did the authors specifically state in the study protocol that subjects underwent cardiac monitoring during droperidol treatment in the ED. ${ }^{18}$ No patients with prolonged QTc were reported in their study following droperidol treatment. These are shown in Table 1 and Table 2.

\section{DISCUSSION}

These studies demonstrated that butyrophenones are effective for the relief of moderate to severe migraine in the ED when compared to placebo or meperidine. They also showed that droperidol may be as effective as prochlorperazine or olanzapine in the relief of benign headache in the ED. Our findings are consistent with reported success rates of $85 \%$ for chlorpromazine, $71 \%$ for sumatriptan, and $61 \%$ for metoclopramide. ${ }^{19}$ Side effects, although minor, were relatively common (10-45\%), and most frequently included akathesia and sedation. Serious side effects such as hypotension or prolonged QTc were rarely reported in the selected studies.

Although three of the six studies included used the classification by the International Headache Society ${ }^{20}$ to define migraine, ${ }^{13-15}$ we included three studies that investigated the use of droperidol in benign headache. ${ }^{16-18} \mathrm{We}$ included them as we wanted to reflect the "real world" of the ED. We believed that differentiating the various types of benign headache, including migraine and tension headache, is challenging, and the studies with benign headache probably included a disproportionately large number of patients with migraine. Further, Trainor and Miner also reported that there was no difference in treatment success rates for various agents, such as sumatriptan, droperidol, and NSAIDs, in migraine and migrainous and tension-type headaches.

It was difficult to perform subgroup analysis for headache relief between the studies on migraine ${ }^{13-15}$ and those on benign headache. ${ }^{16-18}$ The former studies reported subjective headache relief, whereas the latter reported objective headache relief or mean percentage improvement in VAS scores.

Although the selected studies suggested promising results on the effectiveness of butyrophenones, we identified several limitations that prevented their widespread use in clinical practice. These included flaws in the methodologies of these trials and concerns over the optimal dosage of droperidol and the safety of butyrophenones.

The total sample sizes in some of the trials were relatively small $(<100),{ }^{13,15,17}$ and this might have contributed to selection bias. In addition, there were concerns regarding blinding in some trials. ${ }^{16,18}$ In these trials, the physicians were not blinded to the type of medications used to treat the benign headache, and in the trial by Miner and colleagues, blinding was also not achieved to the formulation of droperidol or prochlorperazine. ${ }^{16}$ These would potentially add bias to the report, assessment, and analysis of data. Another important issue in the methology of these trials was that none were designed to specifically investigate serious cardiovascular side effects of butyrophenones, including prolonged QTc. All of them excluded patients with existing cardiac conditions who might be more susceptible to serious cardiovascular adverse effects, and only one trial specified that recruited patients underwent cardiac monitoring while they were treated with droperidol. ${ }^{18}$ Although these studies reported no serious adverse cardiovascular side effects, the above concerns with their methodology might have masked their true prevalence in the diversified patient populations in the "real ED world" treated with butyrophenones for their benign headache.

The concern about serious adverse effects of butyrophenones, particularly prolonged QTc, remains the major limitation toward their widespread use in treating headache.

There have been mixed reports on the cardiovascular side effects of butyrophenones. A "black box" warning was placed on droperidol with regard to the risks of prolonged QTc and torsades de pointes by the Food and Drug Administration (FDA) of the United States. ${ }^{21}$ Other studies, however, seemed to report that droperidol was safe in this aspect. ${ }^{22-24}$ Nuttall and colleagues and Fortney and colleagues reported that IV droperidol up to $1.25 \mathrm{mg}$ was safe in adult surgical patients. ${ }^{22,23}$ Chase and Biros also reported, in their retrospective study, that IV or IM droperidol 2.5 to $5 \mathrm{mg}$ produced very few adverse effects in ED patients with head injury, alcohol or cocaine intoxication, and/or recent seizures..$^{24} \mathrm{We}$ identified some limitations to these studies. The dosages used for droperidol in the surgical patients ${ }^{22,23}$ were relatively lower than the dosages used in the studies identified in this review, which used up to $8.25 \mathrm{mg}$ droperidol. In addition, the ED study, although using a 
similar dosing of 2.5 to $5 \mathrm{mg}$ droperidol, did not investigate the rates of prolonged QTc among the patients. ${ }^{24}$ Hence, it is difficult to extrapolate the findings in these studies to the patients with migraine or benign headache in our identified studies. One of the studies included in our review was terminated prematurely because of the FDA warning. ${ }^{17}$

Other, less serious side effects, such as akathesia and sedation, were common and occurred in 10 to $45 \%$ of patients treated with butyrophenones for their benign headache. In addition, in the haloperidol trial, $16 \%$ of patients who responded to IV haloperidol did not wish their migraine to be treated with the agent in the future because of these side effects. ${ }^{13}$

Another limitation is that there was little suggestion by these studies of the optimal dosing of butyrophenones in the treatment of migraine or benign headache that balanced efficacy and side effects. ${ }^{13-18}$ This is especially important as previous studies have reported a dose-related response of prolonged QTc with droperidol. ${ }^{25,26}$ The chief reason for the failure to identify optimal butyrophenone dosing in the treatment of acute migraine or benign headache was study design. There was only a single study on haloperidol, and it compared an IV infusion of $5 \mathrm{mg}$ of haloperidol in $500 \mathrm{~mL}$ of normal saline over 30 minutes to placebo. ${ }^{13}$ Similarly, only two trials studied IV droperidol; each compared IV $2.5 \mathrm{mg}$ droperidol to IV $10 \mathrm{mg}$ prochloperazine. ${ }^{16,17}$ No other dosages of IV droperidol have been studied to date to identify optimal dosing. On the other hand, there was much variation in the dosing of IM droperidol used in the studies, ${ }^{14-16,18}$ and these ranged from 0.1 to $8.25 \mathrm{mg}$.

Despite the varying dosage regimens, only one study investigated the optimal dosage of IM droperidol. ${ }^{14}$ In that article, the authors reported no linear dosedependent relationship between IM droperidol and its efficacy or side effects and suggested an optimal dosing of $2.75 \mathrm{mg}$.

These issues challenge the broad adoption of butyrophenones for the treatment of migraine or benign headache.

There were some limitations to our review. We only included studies in English and could have excluded relevant studies published in other languages. In addition, there could always be selection bias by our reviewers. Finally, we were also unable to exclude publication bias. Trials reporting negative findings are less likely to be published and more likely to be excluded from systematic reviews. We did not perform a hand search of recent conference proceedings to identify unpublished trials. Nevertheless, we had tried to minimize such bias by doing a hand search of the reference lists of identified papers.

\section{CONCLUSIONS}

Available data suggest that butyrophenones are effective for the relief of migraine or benign headache. However, at this time, the lack of a clear dosing strategy, the prevalence of adverse effects, and a small risk of serious cardiovascular adverse effects make it difficult to recommend butyrophenones above agents with similar effectiveness and fewer problems.

Competing interests: None declared.

\section{REFERENCES}

1. Vinson DR. Treatment patterns of isolated benign headaches in US emergency departments. Ann Emerg Med 2002; 39:215-22.

2. Silberstein SD, Saper JR, Freitag F. Migraine: diagnosis and treatment. In: Silberstein SD, Lipton RB, Dalessio DJ, editors. Wolff's headache and other head pain. 7th ed. New York: Oxford University Press, 2001. p. 121-237.

3. Colman I, Rothney A, Wright SC, et al. Use of narcotic analgesics in the emergency department treatment of migraine headache. Neurology 2004;62:1695-700.

4. Friedman BW, Kapoor A, Friedman MS, et al. The relative efficacy of meperidine for the treatment of acute migraine: a meta-analysis of randomized controlled trials. Ann Emerg Med 2008;52:705-13.

5. Bigal ME, Lipton RB. Excessive acute migraine medication use and migraine progression. Neurology 2008;71:1821-8.

6. Dodick D, Lipton RB, Martin V, et al. Consensus statement: cardiovascular safety profile of triptans $(5-\mathrm{HT} 1 \mathrm{~B} / 1 \mathrm{D}$ agonists) in the acute treatment of migraine. Headache 2004;44: 414-25.

7. Richman PB, Reischel U, Ostrow A, et al. Droperidol for acute migraine headache. Am 7 Emerg Med 1999;17:398-400.

8. Fisher H. A new approach to emergency department therapy of migraine headache with intravenous haloperidol: a case series. 7 Emerg Med 1995;13:119-22.

9. Mascia A, Afra J, Schoenen J. Dopamine and migraine: a review of pharmacological, biochemical, neurophysiological, and therapeutic data. Cephalalgia 1998;18:174-82.

10. Trainor A, Miner J. Pain treatment and relief among patients with primary headache subtypes in the ED. Am 7 Emerg Med 2008;26:1029-34.

11. Jadad AR, Moore RA, Carroll D, et al. Assessing the quality of reports of randomized clinical trials: is blinding necessary? Control Clin Trials 1996;17:1-12. 
12. International Headache Society Committee on Clinical Trials in Migraine. Guidelines for controlled trials of drugs in migraine. First edition. Cephalalgia 1991;11:1-12.

13. Honkaniemi J, Liimatainen S, Rainesalo S. Haloperidol in the acute treatment of migraine: a randomized, double blind, placebo controlled study. Headache 2006;46:781-7.

14. Silberstein SD, Young WB, Mendizabal JE, et al. Acute migraine treatment with droperidol: a randomized double blind, placebo controlled trial. Neurology 2003;60:315-21.

15. Richman PB, Allegra J, Eskin B, et al. A randomized clinical trial to assess the efficacy of intramuscular droperidol for the treatment of acute migraine headache. Am 7 Emerg Med 2002;20:39-42.

16. Miner JR, Fish SJ, Smith SW, et al. Droperidol vs. prochlorperazine for benign headaches in the emergency department. Acad Emerg Med 2001;8:873-9.

17. Weaver CS, Jones JB, Chisholm CD, et al. Droperidol vs. prochlorperazine for the treatment of acute headache. $f$ Emerg Med 2004;2:145-50.

18. Hill CH, Miner JR, Martel ML. Olanzapine versus droperidol for the treatment of primary headache in the emergency department. Acad Emerg Med 2008;15:806-11.

19. Kelly AM. Specific pain syndromes: Headache. In: Mace S, Ducharme J, Murphy M, editors. Pain management and sedation: emergency department management. New York: McGraw-Hill, 2006. p. 279-86.
20. Headache Classification Committee of the International Headache Society. Classification and diagnostic criteria for headache disorders, cranial neuralgias and facial pain. Cephalalgia 1988;8:1-96.

21. Jackson CW, Sheehan AH, Reddan JG. Evidence-based review of the black-box warning for droperidol. Am 7 Health Syst Pharm 2007;64:1174-86.

22. Nuttall GA, Eckerman KM, Jacob KA, et al. Does low dose droperidol administration increase the risk of drug induced QT prolongation and torsades de pointes in the general surgical population? Anesthesiology 2007;107:531-6.

23. Fortney J, Gan T, Graczyk S, et al. A comparison of the efficacy, safety and patient satisfaction of ondansetron versus droperidol as anti-emetics for elective outpatient surgical procedures. S3A-09 and S3A-410 study groups. Anesth Analg 1998;86:731-8.

24. Chase PB, Biros MH. A retrospective review of the use and safety of droperidol in a large, high risk inner city emergency department patient population. Acad Emerg Med 2002;9: 1402-10.

25. Dershwitz $M$. There should be a threshold dose for the FDA black-box warning on droperidol. Anesth Analg 2003;97: 1542-3.

26. Lischke V, Behne M, Doelken P, et al. Droperidol causes a dose dependent prolongation of the QT interval. Anesth Analg 1994;79:983-6. 